$Q$-and T-enzymes. These names were deliberately initiated by Prof. Stanley Peat and the late Sir Norman Haworth to apply to enzyme preparations the precise function and purity of which it was thought unwise to speculate on by coining a specific name. The names were always intended to be replaced by explicit nomenclature when the purity and, particularly, the function of the enzyme preparations had been clearly characterized. The course of events has shown the wisdom of the use of 'initial' names. Thus $R$-enzyme has proved to be a mixture of two enzymes performing chemically identical functions, but on different substrates ${ }^{1} ; Z$-enzyme proved ultimately to be identical with a well-known enzyme, $\alpha$-amylase ${ }^{2}$. In the glycogen field, by contrast, one name for an enzyme has survived only because it became abbreviated. to an 'initial' name, that is, $P R$ enzyme. Speculation on the nature of its action has led it variously to be called prosthetic-group removing enzyme, protein-rupturing enzyme and $p$ hosphate-removing enzyme ${ }^{1}$. Similarly a glycogen hydrolase preparation, amylo-1, 6-glucosidase, was recently reported in Nature to depend for its action on two enzymes, a hydrolase and a transferase ${ }^{3}$. The bestintentioned of names "gang aft a-gley", and a policy of caution will impose less of a burden on the literature than one which provides names that later prove not to mean what they say. To me this policy of caution provides the most prudent way of tempering the advice attributed to one of the first editors of this Advances series, the late C. S. Hudson: "If you can't name it, don't make it!" W. J. WHELAN

1 References to the original literature are given in a review by Whelan, W. J., Nature, 190, 954 (1961).

${ }^{2}$ Manners, D. J., Adv. Carbohydr. Chem., 17, 371 (1962).

${ }^{3}$ Abdullah, M., and Whelan, W. J., Nature, 197,979 (1963), Brown, D. H., Illingworth, B., and Cori, C. F., ibid., 197, 980 (1963).

\section{SPACE DYNAMICS}

Space Flight

Vol. 2: Dynamics. By Krafft A. Ehricke. (Principles of Guided Missile Design.) Pp. xxi +1,210. (Princeton, N.J.: D. Van Nostrand Company, Inc.; London: D. Van Nostrand Company, Ltd., 1962.) $230 s$.

THIS massive text-book could have been published as six 200-page monographs, each an important and pioneering contribution to the dynamies of space flight. Most authors would be well content to have written one of these six contributions. But Mr. Ehricke is cast in the heroic mould, and has accomplished single-handed what would normally occupy a large team of writers, each with a different point of view and style.

The first section of the book (Chapters 1-2) covers the dynamics of sub-orbital ballistic flight (including orbit-toground trajectories) and satellite orbits, including ascent paths and perturbations. It is a valuable feature of this and other sections of the book that Mr. Ehricke keeps the mathematics as elementary as possible, is clear in his exposition and gives a wealth of illustrations (more than 600 in all) in the form of diagrams and graphs of close grid: consequently, his book should be readily intelligible not only to mathematicians but also to physicists and engineers. Chapter 2 is, however, the least satisfactory part of the book because it is rather outdated: the discussions of the effects of the Earth's gravitational field and atmosphere seem to have been written about 1958 and, despite the addition of more recent titbits, are defective.

Chapter 3 deals with transfer between orbits about the same centre of attraction, from the solved problem of transfer between circular coplanar orbits to the recalcitrant one of transfer between non-coplanar ellipses. Mr. Ehricke's bold and pragmatic attack on the problem, using elementary concepts, is in refreshing contrast to the usual calculus-of-variations approach, which consists in writing down innumerable insoluble equations. $\mathrm{Mr}$. Ehricke can perhaps be criticized for not making it clear that the rules-of-thumb he propounds do not always provide the answers; but it is far better to have some rules than none. He completes the subject in Chapter 4, which covers transfers between one central force field and another, and is largely concerned with hyperbolic orbits.

The next section (Chapters 5 and 6) discusses powered ascent paths and their optimization, taking into account thrust, lift, drag and the influence of gravity.

Chapter 7 is on low-thrust flight, which is important because in future interplanetary journeys the power unit is likely to be an ion or plasma rocket, with a much higher efficiency than a chemical rocket but a much lower thrust. This chapter runs to 233 pages and could stand as a book on its own, for it treats the subject more thoroughly than existing texts. Chapter 8 discusses lunar flights, including Earth-Moon flight paths, lunar circumnavigation, impact and landing, and lunar satellites. Again it is an impressively thorough survey, illuminated by much original work. The book ends with a long and systematic treatment of the dynamics of interplanetary flight, covering practical aspects of flights to the various planets-the best departure times for flights, the most convenient orbits, etc.

The book is excellently printed on good-quality paper, includes examples at the ends of chapters and lists of references (which are, however, almost all pre-1960). There is some vacillation about units of length, with nautical miles, feet and kilometres all making an appearance, but this is a minor defect. Misprints are very rare, and it is unfortunate that one of them affects the date given for the launching of Sputnik 1, which is in error by a year.

This book will remain as one of the enduring monuments of astronautics when most of the multi-million-dollar satellite launchings have been forgotten, and any organization which spends large sums on space activities will find it difficult to refute the conclusion that a copy should be bought for every appropriate member of its staff.

D. G. King-Hele

\section{THE EARTH SCIENCES}

Mining for Metals in Wales

By F. J. North. Pp. viii $+112+8$ plates. (Cardiff: National Museum of Wales, 1962.) 12s. 6d.

\section{The System of Mineralogy}

By James Dwight Dana and Edward Salisbury Dana. Vol. 3: Silica Minerals. Seventh edition entirely rewritten and greatly enlarged by Prof. Clifford Frondel. Pp. xii +334. (New York and London: John Wiley and Sons, Inc., 1962.) $60 s$.

\section{Volcanoes and their Activity}

By A. Rittmann. Translated from the Second German Edition by E. A. Vincent. Pp. xiv + 305. (New York and London: Interscience Publishers, a division of John Wiley and Sons, Inc., 1962.) 90s.

\section{Introduction to Physical Geology}

By Prof. Chester R. Longwell and Prof. Richard F. Flint. Second edition. Pp. 504. (New York and London: John Wiley and Sons, Inc., 1962.) $60 s$.

$\mathrm{D}$ R. NORTH'S Mining for Metals in Wales contains an account of the history of metalliferous mining in the Principality; together with a description of the geological mode of occurrence of the many varieties of ore that have been worked there. Metalliferous mining has now almost ceased in Wales, either for economic reasons, or through exhaustion of the sources. Attempts to revive the mining of lead and zine were made a few years ago, 